\title{
Somalia: Making Human Rights Central to the State Rebuilding
}

\author{
Dr. Ahmed Ali M. KHAYRE
}

\begin{abstract}
Somalia has been without any effective, central government for the last two decades. The UN Commission on Human Rights stated that "without a central administrative structure, it is not possible to lay down the foundations of a permanent program of human rights for Somalia". On the other hand, there is a widespread consensus that, for a functioning central authority to be constituted, human rights protection should be made central to all attempts. Admittedly, it seems that the current effort to rebuild the collapsed state of Somalia is geared towards restoring a 'minimalist'state that can restore law and order without further thinking about the contextual circumstances and actual reasons, particularly human rights violations, which led to the collapse in the first place. This paper argues that it makes no sense rebuilding the same abusive state institutions. The argument proceeds in three stages. Firstly, it critically analyses the previous failed endeavours that tried to recreate the old order, without human rights components being implemented in the process. Secondly, it examines the role of human rights in creating a legitimate authority that can adequately protect human rights of the citizens. Finally, this paper suggests ways to embed human rights into all facets of state rebuilding.
\end{abstract}

Keywords: Human Rights, Somalia, State Collapse, Humanitarian Law, Africa, Horn of Africa.

\section{Introduction}

Prior to the adoption of the United Nations Charter, the international law, by and large, concerned only international relations between sovereign states. The treatment any state accorded to individuals under its jurisdiction was left to the discretion of the state and its domestic laws and it was largely considered an internal affair of the sovereign country (Reisman, 1990, pp. 866-876).In that connection, human rights were recognised as a subject "not, in prin-

Dr. Ahmed Ali M. KHAYRE

Human Rights and Humanitarian Law Researcher

E-mail: ahmedakhayre@gmail.com

Conflict Studies Quarterly

Issue 21, October 2017, pp. 22-49

DOI:10.24193/csq.21.2

Published First Online: 10/03/2017 
ciple regulated by international law". In view of that, the Permanent Court of Internal Justice held in that context, "the jurisdiction of a State is exclusive within the limits fixed by international law," and in consequence "[a]s regards such matter, each State is sole judge" (Nationality Decrees Issued in Tunis and Maroco, Advisory Opinion, 1923).

The situation became much more complicated after the Second World War in comparison with the previous periods. The changes to international law with respect to the treatment of individuals are sometimes known as the "Nuremberg principles" because they were initially developed during the Nuremberg trials that followed the Second World War (Nash, 2009, p. 38). According to Kate Nash (2009, pp.2, 3), this principle influenced international law in two ways. For a start, it was no more acceptable to hide behind the orders of the superiors, thus every individual is accountable for the contraventions of international humanitarian law. Secondly and perhaps more significantly, human rights defenders became concerned with how citizens are treated within state jurisdiction. Nash argues that "it is only with collusion of state agents that human rights are violated, and only states can secure and enforce within their own territories".

Human rights, arguably "has become a signal indicator for whether states are working in a post-conflict or international setting" (Ignatieff, 2005, pp. 59-75). Ignoring human rights protection in the attempts to reconstruct the Somali state made the situation more complicated. The following Somali adage is relevant in this case:"xaajo haddii lagu heshiin waayo waxaa ka maqan ama kusaa'id ah arrin", roughly translated it means "if parties to a conflict cannot agree on an issue, either there is something missing from the agenda or something irrelevant in it". There are a lot of things that have been missing from the peace and reconciliation conferences organised for Somalia, but I suggest that the most fundamental thing that was neglected was the embedding of human rights norms into all aspects of state-building from the start.

This paper investigates the attempts to make human rights prominent in countries that are rebuilding without effective central governments and analyses the case of Somalia. The key conceptual issues pertaining to the role of human rights in state reconstruction are explained and then human rights protection with regard to the broader undertakings of state reconstruction and peace-building are considered. Similarly, this paper examines how to ensure the embedding of proper human rights accountability mechanisms in all attempts to rebuild collapsed state institutions.

\section{Efforts to Reconstruct the Collapsed State of Somalia: The Missing Link}

In general, two different phases can be identified with respect to the efforts aimed at reconstituting an effective central government in Somalia. In the first decade after the collapse of the central authority from 1991-2000, there had been no government, no representation in the international fora, not even a nominal government. The seats of Somalia in international organisations where Somalia was a member remained unoccu- 
pied (Sahnoun, Prevention in Conflict Resolution: The Case of Somalia, 1994). However, after the year 2000, when the first Transitional National Government was established, there have been feeble transitional governments. Although recognised by international and regional organisations as "legitimate" governments, these transitional governments have not had control over Somalia outside parts of the capital city (ICG, 2011). In that respect, when the first transitional government was established in 2000, "no government structure, such as a civil service, has existed in Somalia for more than a decade. The TNG inherited no personnel, buildings, archives, forces of law and order or taxcollecting capacity" (UNSC, 2001)".

However, the attempt by external mediators to find a durable solution for the Somali crisis was complicated from the outset by lack of understanding of the complexity of the situation. As Mohamed Sahnoun, UN Secretary-General's Special Representative for Somalia observed during the early stages of the conflict, "[t]o look for quick fixes as political solutions, without taking into account the local realities is nonsense". According to his informed opinion, "people in New York who knew nothing of the realities in the field make hasty and uncalled for decisions and persist in having them implemented, despite evidence of mismanagement and strong objection of the people in the field" (Sahnoun, 1997).

Even though human rights violations have been ongoing in many parts of Somalia unabated for over a decade, in 2004 the independent expert on the situation of human rights in Somalia, Ghanim Alnajjar, sounded an overly optimistic note on the overall human rights situation in Somalia. He confidently proclaimed that " $[t]$ he past year has been marked by continued efforts towards political stability as well as the persistence of distinct variations between regions in the observance of human rights" (UN Commission on Human Rights, 2004). Strangely enough, the names of the individuals consulted by the independent expert in his various visits to the country as well as to neighbouring countries included the names of prominent warlords who were accused of human rights violations.

Equally, after the conclusion of the Somali peace process in Nairobi in 2004 and the establishment of the Transitional Federal Government of Somalia, the independent expert on the situation of human rights in Somalia, Ghanim Alnajjar, observed that the outcome of the conference indicated "a cautious optimism for peace and reconciliation for Somalia" (UN Commission on Human Rights, 2005). However, the optimism seemed to have been a short-lived one. Even though the independent expert recognised the link between human rights observance and the attainment of peace and stability when he "encouraged the international community to support the Transitional Federal Government and Somali civil society in the critical human rights work that must occur if peace and security are to prevail in Somalia" (UN Commission on Human Rights, 2005). Nowhere in the report is the role of the current leaders in past human rights violations 
mentioned or discussed. It seems as if the past activities of these "leaders" bear no relevance to the present and future endeavours.

However, as Amnesty International observed: "[b]uilding respect for human rights cannot be solely dependent on the complex and lengthy process of peacemaking, although peace between the armed groups is clearly essential for reconstruction" (Amnesty International, 1995, p. 6). In another vein, Amnesty International articulated that there is an intrinsic interplay between the protection of human rights and the quest to achieve peace. In that respect, any peace "agreement should incorporate specific human rights guarantees and should contain effective implementation and monitoring mechanisms to ensure that human rights are respected and promoted" (Amnesty International, 1995). Amnesty International emphasises the importance of the "commitment by all parties to respect and promote human rights and humanitarian standards". However, the organisation realises that the pledges of faction leaders are worth little, because "[a]ll the Somali political organisation have made nominal and 'paper' commitments to peace, reconciliation and human rights in various conferences and peace agreements signedby their leaders" (Amnesty International, 1995, p. 13). The same individuals and their supporters were continuously invited to attend the next reconciliation conference without having seriously been questioned on their willingness to end the conflict. The reasons for their failure to abide by the previous commitments have not been investigated or ascertained.

There is a general consensus that human rights protection and the improvement of the human rights situation of any particular country plays a vital role in "preventing the escalation of conflict into serious violence, as well as establishing a basis for longterm stability and development" (Hannum, 2006, p. 5). In the case of Somalia, almost all the accords reached by the faction leaders gave warlords the mandate to construct a legitimate authority. It is claimed both by the international mediators and the warlords that these agreements would establish human rights-based institutions. In effect, this endeavour amounted to what one commentator called, in another context, "warlord democratisation" (Khayre A. A., 2016). This proposition is contradictory because it claims that human rights are priority, while at the same time empowering the same individuals accused of perpetrating heinous human rights violations (Khayre A., 2014). Increasingly it is widely acknowledged that the provision of security is the most primary pillar in peace-building efforts, and at the same time the "building or rebuilding of public institutions is key to sustainability" (Samuels, 2006, p. 2).In fact, it is through state institutions that the future conflicts can be managed and perhaps recurrences of violence can be avoided (Samuels, 2006, p. 2). As the experiences in many post-conflict countries vividly demonstrate, silencing the guns without "modification of the political environment" will probably be unsuccessful, no matter the amount of external assistance and encouragement (Samuels, 2006). Furthermore, as Krishna Kumar observes, 
"rebuilding institutional infrastructure shattered during conflict is as important, if not more important than physical infrastructure. It is an area which has largely been overlooked by the international community in the past" (Kumar, 1997). The implementation of human rights requires a political reconstruction of the country. As the Commission on Human Rights recognised: "until such reconstruction, it is difficult to see how any human rights programme can be implemented effectively" (UN Commission on Human Rights, 1994, p. para.26).In that respect, human rights should be given a prominent position in the efforts to end the conflict because "the human rights dimension signals a fundamental change in the nature of the state" to be reconstructed (Shabas, 2007, p. 48).

\section{Human Rights Dimension in Reconciliation Attempts and Peace Agreements}

In general, the fundamental purpose of international "peace-building"is to create a peaceful environment where fears of returns to the violent past are eliminated or at least substantially reduced in societies emerging from devastating civil warfare. The former Secretary-General Kofi Annan defines the term "peace-building" as "actions undertaken at the end of a conflict to consolidate peace and prevent a recurrence of armed confrontation" (Annan, 1998, p. para. 63). The situation appears observably much more precarious in fully collapsed states like Somalia, where all the central state institutions are entirely ruined and almost everything needs to be started from scratch. As Lederbacht argues, achieving peace requires "long-term commitment to establishing an infrastructure across the levels of a society", which "empowers the resources for reconciliation from within that society and maximises the contribution from outside" (Lederacht, 1997, p. xvi).

Additionally, the achievement of physical security and stability is the first of many challenging steps. In fact, sustainable peace and stable governance structure can only be put in place if functioning and effective state institutions are re-instituted and the newly constituted state is capable once again "to mediate effectively between distrustful ethnic groups, and the parties slowly gain confidence in the safeguards contained within their new ethnic contract" (Rothschild, 1998, p. 349). The best way to do that is to establish state institutions based on the rule of law, and at the same time be accountable to the general public. With respect to the inclusion of human rights language in the peace agreements, as Hannum observes:

The manner of implementation and the commitment of both the international community and national actors to that implementation are likely to be more important than the language in an agreement- although the latter at least creates the expectation that human rights concerns will be addressed in the immediate post-settlement period (Hannum, 2006, p. 44).

To be sure, after years of deadly conflict, signing a peace agreement or a military victory by one of the warring factions is merely the beginning. In fact, the silencing of guns 
presents "a new set of opportunities that can be gasped or thrown away" (Rothstein, 1999). More often than not, the success and failure of such processes is contingent upon how the post-conflict transition is managed. In order to prevent violent conflict from recurring, it is essential to somehow address the root causes of the conflict, not merely "surface manifestations such as the military culture and proliferation of weapons" (Rothstein, 1999, p. 224). In view of that, "the process of peace-building calls for new attitudes and practices: one that is flexible, consultative and collaborative and that operate from a conceptual understanding of the root causes of conflict" (Spence, 2001, p. 137).

It is evident that, without institutional reform and the creation of a human rights-based governance system, including robust monitoring mechanisms and empowering rights institutions, human rights clauses alone will be insufficient (Hannum, 2006, pp. 46,47). Furthermore, some evidence seems to suggest "the formal enumeration of human rights provisions in settlements correlates only weakly, if at all, with the quantity and quality of human rights protection during and after peace implementation (Putnam, 2002, p. 238). As Stedman notes:

All too often in the 1990s international and regional organizations were sent to implement peace agreements in extremely challenging environments where no major state possessed a security interest. When implementers were challenged, the mission failed, usually with catastrophic consequences (Stedman, Rothchild, \& Cousens, 2002).

According to Brahimi (2007), when violent conflict erupts in a country, it is usually difficult to obviate the downward trajectory satisfactorily. International efforts to help end the conflict and establish peace and sustainable stability is often insufficient. In general, there are two recurring limitations that might negatively influence the situation. First, "insufficient knowledge and understanding of local and regional conditions is one; the other is the low priority given by international players to the rebuilding of national institutions". In effect, although the assistance of the international community can help conflict marred societies to end hostilities, "experience indicates that any state-building intervention will be sustained only through national structures” (Brahimi, 2007, p. 5). In the Somali context, the United Nations frankly admitted that any gains made on the humanitarian front by the United Nations or other donor countries will amount to nothing and will not positively change the extremely fragile situation, 'in the face of continuing insecurity and in the absence of a structured indigenous capacity' to deal with the different challenges associated with societies affected by the prolonged conflict (UNSC, Further Report of the Secretary- General on the United Nations Operations in Somalia, 1994, p. para.3). Equally, any other achievement in the absence of legitimate state authority will probably be a temporary one. 
The United Nations invested a lot of resource in an attempt to rebuild state institutions in Somalia during the UNOSOM II period in the early 1990s. In that regard, the Secretary-General reported to the Security Council:

[p]rogress is being achieved in the rebuilding of institutions, especially the police and the judicial system. These achievements are grounds for hope that the Somali people can resume normal lives after the hardship that they have suffered over the last several years (UNSC, Further Report of the SecretaryGeneral on the United Nations Operations in Somalia, 1994, p. para.54).

In the same report, the Secretary-General stated, "there has been a significant deterioration in the security situation, especially in Mogadishu, due to the resumption of inter-clan fighting and to a further increase in banditry" (UNSC, Further Report of the Secretary- General on the United Nations Operations in Somalia, 1994, p. para. 54). This demonstrates the importance and the necessity of creating political consensus and a legitimate authority before any rebuilding of institutions is undertaken. Any attempt to rebuild institutions will probably be futile in the absence of a legitimate national authority.

\section{Rebuilding the Old System or Starting from Scratch?}

Once the guns are silenced after prolonged political violence, for the attained relative peace to be sustainable in the long-term, the hard work to create human rights-based governance should start as soon as practicable. As Katoboro suggests:

The solution lies in restoring (creating new) practices and institutions such as a new democratic constitution based on separation of powers, and checks and balances; holding elections based on political party competition. Autonomous bodies such as human rights institutions, electoral commissions, a vibrant civil society, a multiparty system, a strong constitutional court, and an open, free critical mass media will strengthen the organs of a re-emerging State (Katoboro, 2003, p. 3).

Furthermore, there is an obvious link between the extent of the collapse of state institutions and the challenges encountered in restoring political order. However, there might be a silver lining amid all the challenges and difficulties caused by state collapse. Beyond this seemingly irresolvable puzzle, there might be an:

opportunity to start from scratch without encrusted obstacles of the ancien regime attitudes, red tape, bureaucracy, and conservatism. It provides the opportunity for policy makers to be creative and innovative in rebuilding democracy and good governance in their countries (Katoboro, 2003, p. 8).

In almost all attempts to reconstruct the collapsed state of Somalia, it seems that there has only been one strategy which involves recycling the old regime, minus the president 
and other senior officers, with a few negligible cosmetic alterations. Evidently, that has miserably failed to allay the fears of the general public and communities that another predatory system dominated by one clan will be put in place. As Salman Ahmed points out, "for peace to be self-sustaining the reconstruction process cannot be predetermined by generic templates and arbitrary time-frames; it must be shaped by the aspirations and deliberations of the men and women who will live with the results" (Ahmed, 2005, p. 169).

Given the fact that disrespect for the rule of law and lack of legal mechanisms to deal with the grievances of the citizens is deemed to be one of the root causes of the armed conflicts around the world, it is imperative to make sure that national institutions are capable of responding adequately and peacefully to the complaints and injustices before they cause violent conflict (UNSC-UNGA, 2003, p. para.18). According to the United Nations, "[r]espect for human rights and the rule of law are necessary components of any efforts to make peace durable" (UNGA-UNSC, 1998, p. para.72). Obviously, silencing the guns and creating a relatively stable environment is not enough to build sustainable political orderin collapsed states. However, "Even in those instances where security is established, state-building has largely resulted in cosmetic political change and created weak, unstable, or even criminal states". In the former President of Liberia's words: "The state we produced turned out to be a criminal state, legitimized by elections" (Samuels, 2006, p. 4). Regrettably, it seems this is what has been unsuccessfully attempted in Somalia.

Predictably, sometimes it is counterproductive to rebuild the old oppressive institutions, particularly when "Previously existing governance structures have been shown to be contributors to state fragility or failure in cases where they promote social, ethnic and/ or economic exclusion and inequalities; ignore human rights; abuse the rule of law; engage in corrupt practices, etc" (Brinkerhoff, 2005, p. 11). Somali leaders explicitly proclaim their desire to bring back the pre-1991 governance system and its institutions, for that system is associated with peace and stability. However, these individuals perilously ignore the dominant role of the previous government institutions and leaders in state collapse. The police and military forces of the last military government were predatory, oppressive and corrupt. As Bruce Baker observes in another context "[s]imply changing the structure of organizations rarely affects operational behaviour, because it does not alter what the employees themselves think is expected of them" (Baker, 2006, p. 34). In Somalia, all consecutive governments established after the implosion of the central government in 1991, former military and police officers were called back without any vetting process and irrespective of their past records. Likewise, other individuals who occupied prominent positions in the last military government are still calling the shots. It is no wonder that citizens distrust the security forces and other government agents. It is against this backdrop that the attorney general of the country characterises the 
central prison in the capital as a "concentration camp", referring to the way the prisoners are treated. ${ }^{1}$

It seems that more importance is attached to order and stability "even when the prevailing order is unjust". Furthermore and perhaps more importantly, "this emphasis on order and stability clearly serves the interests of Western powers concerned about international insecurities stemming from drug trafficking, terrorism, or internal armed conflict abroad" (Call, The Fallacy of the 'Failed States', 2008, p. 1496). If the emphasis is blindly and narrowly put only on security without taking human rights into consideration, then it can lead to legitimising warlords and other human rights violators. Given that the state institutions were predatory, corrupt and grossly mismanaged the daunting challenge for state rebuilding in such circumstances is how to create a strong, legitimate and effective state. As Richard Caplan notes: "to be legitimate the exercise of authority also requires mechanisms of accountability" (Caplan, 2004, p. 61).

It may be pointed out that attempts and policies solely focusing on security aspects mostly ignore the need not to reincarnate the authoritarian state but to build a new human rights-based state where the protection of the rights and dignity of the citizens are made central. Along the same line, a report compiled by a United Nations commissioned High-level Panel persuasively acknowledged the necessity to look beyond security paradigms when rebuilding states and wrote: "[a]long with establishing security, the core task of state building is to create effective public institutions that, through negotiations with civil society, can establish a consensual framework for governance within the rule of law". The UN report put further emphasis on the importance of making the protection of human rights central to all the policies aimed at state building and stated:

Relatively cheap investments in civilian security through police, judicial and rule-of-law reform, local capacity-building for human rights and reconciliation, and local capacity-building for public sector service delivery can greatly benefit long-term peace-building. This should be reflected in the policies of the United Nations, international financial institutions and donors, and should be given priority in long-term policy and funding (UN, Report of the SecrataryGeneral's High-Level Panel on Threats, Challenges and Change- A More Secure World: Our Shared Responsibility, 2004, p. para.229).

Nevertheless, it is not as straightforward as it seems at first glance. It is necessary to ensure the centrality of human rights to the efforts to reform or rebuild state institutions; otherwise it may lead to empowering the wrong people and unintended perpetuation of human rights abuses. Furthermore, and more pertinently, pursuing narrow security objectives can be damaging to the future prospect of establishing a self-sustaining state

1 See, https://www.youtube.com/watch?v=8mQ3ZdEZzD0 
based on human rights. As Charles Call aptly observes, "state-building can jeopardise peace, and contribute to insecurity and group tensions". Undoubtedly, the situation is much more precarious " $[\mathrm{W}]$ here external donors provide resources to corrupt, predatory central governments in the name of strengthening their institutions, state building only advances abusive authority and fuels sentiment and armed resistance" (Call, The Fallacy of the 'Failed States', 2008, p. 1499).

As Brahimi points out, to construct a state "there must be consensus on the type and shape of the state to be built and agreement between all parties as to the process that will be used to create the state" (Brahimi, 2007, p. 7). As the experience of complete collapse of state institutions in Iraq after the removal of Saddam Hussein abundantly demonstrates "the provision of order is intimately linked to the much longer-term project of building a sustainable, efficient and representative state" (Dodge, 2005, p. 707). However, the pertinent question is: is it enough to return to the old status quo or is more needed to construct a new credible entity? As the experience in Somalia for the last two decades painfully shows, recreating old abusive state institutions will not be enough to achieve sustainable peace, security and enhance the observance of human rights standards.

\section{Constitution Making in Somalia: Continuously Reinventing the Wheel}

As experiences elsewhere in post-conflict situations demonstrate, creating a legal framework "within which law enforcement and judicial institutions could operate" is the first step (Strohmeyer, 2001, p. 173). Without a clear legal framework and judicial personnel appointments, the workings of the police, judges and prisons will be hampered (Strohmeyer, 2001). In Somalia, during the military government, the country was ruled through a combination of presidential decrees, emergency laws and personal whim. However, before the military took over, the country had a popularly approved constitution adopted in 1960. In fact, during nine years of civilian democratic rule from 1960-1969, the 1960 constitution had been the law of the land and there was a clear separation of powers.

After the collapse of the central government, the Somali people had a choice: to use laws that existed prior to the military coup of 1969 or to create new applicable laws. Obviously, there are challenges associated with both choices. For instance, there are insufficient personnel with knowledge of the previous laws or expertise in enforcing or creating new ones. If properly conducted, the process of constitution making "can provide a forum for the negotiation of solutions to the divisive or contested issues that led to violence" (Samuels, 2006, p. 5). Institutional reform is essential in the reconstruction of collapsed states like Somalia. Most often, abuses of power and incompetent governance lie at the heart of the state collapse and to obviate these problems "structures must be established in order to re-legitimise state power and make the peaceful management 
of conflicts possible" (Baechler, 2004, p. 7). Constitution making is a tremendously significant part of state reform after devastating conflict. However, constitutional reform alone will probably not be sufficient. After a protracted civil war, the security sector is entirely in ruins. The reconstruction and reform of the security sector is indispensable for any future political dispensation to be functional.

It is not enough to reconstitute the state's monopoly on violence, but this power ought to be "supported by appropriate political and democratic controls" (Baechler, 2004, p. 16). In addition, as Kenneth Bush observes: "status quo ante bellum is rarely a desirable state of affairs, and in most cases years of violent conflict and profound changes in the international political economy have destroyed any chance of returning to the status quo" (Bush, 1997, p. 2). Brahimi advises, "[c]onstitution-drafting should be closely linked to the peace-process, must not be rushed, and should be carefully aligned with existing legal provisions" (Brahimi, 2007, p. 4). Surely, "[t]o build a state, there must be consensus on the type and shape of the state to be built and agreement between all parties as to the process that will be used to create that state" (Brahimi, 2007, p. 7).

The Somali people have had little say in deciding what kind of governance system best suits their country and its population. For example, the neighbouring countries and their negotiators pressured their client warlords to adopt a federal system of government without any meaningful discussion on its merits, focusing solely on power sharing or what some commentators call a "division of spoils" (Hart, 2003). The result is a provisional constitution that is likely to create new problems in lieu of solving existing ones. The reason is that, as Afyare Elmi points out, the constitution making process was "fundamentally flawed because political expedience, secrecy, exclusion and hastiness mar [red] the mandate and selection of the commission members and the drafting of the document..." (Elmi, 2012).

As Jamal Benomar notes, in another context, "Constitutions produced without transparency and adequate public participation will lack legitimacy" (Benomar, 2004, p. 89). Nevertheless, "the formalized division of power along identity or ethnic lines appear to entrench the ethnic and divisive positions that have fuelled the conflict, rather than ameliorated them" (Samuels, 2006, p. 13).

By and large, constitution-making in post-conflict countries go through two stages. The first step is to draft a provisional charter "to delegate the formation and operation of an interim authority". The second stage is "to draft and adopt a more permanent constitution and to hold democratic elections". Experience, elsewhere in post-conflict countries in Africa, show that the choice of most countries had been to draft a new constitution (Uganda, Ethiopia and Mozambique) (Katoboro, 2003). However, even though new constitutions full of human rights provisions are drafted and adopted, most of these countries are ruled by authoritarian regimes with little respect for the rule of law. 
In Somalia, after more than a decade of the existence of a transitional government and charter, no real attempt has been made to rebuild the judicial system. Practically, there are no national courts of the first instance or appellate courts to say nothing about a constitutional court. In 2011, on constitution making efforts in Somalia, the SecretaryGeneral stated: "[t]he Somali Constitution Process is essentially about reconciliation, peace-building, and nation-building. The process must reconcile and unite the Somali people in a common cause" (UNSC, 2011, p. para.43). Since the collapse of the central government in 1991, three interim charters have been crafted. At the time of writing, a provisional constitution is in place and the plan is to be approved by a popular referendum in 2016. Given the security situation of the country and the divisions between different groups, it is unlikely that it will be adopted in that manner. A selected group of citizens representing different regions may be asked to adopt the constitution. For the new constitution to become living document state institutions must be rebuilt and empowered and new leaders should be serious about the implementation of its provisions.

\section{Human Rights Guarantees in the Somali Constitutions}

Generally, the inclusion of human rights clauses in the drafted constitutions is seen as a step forward in the protection and promotion of human rights. However, as experience in Somalia demonstrates, if the constitution making is not accompanied by state reform and implementation, the provisions in the new constitution remain just words. Furthermore, empirical examinations demonstrate that there is no sufficient evidence to indicate that inclusion of human rights provisions in the constitution "produced an observable improvement on human rights behaviour" (Keith, 2002, p. 134). In Somalia, two Transitional Charters and the current provisional constitution have been drafted since the collapse of the central government in 1991. Let us now turn to the human rights provisions in these charters.

In its preamble, the Transitional National Charter adopted in 2000 recognises "the gross violations of human rights inflicted upon the Somali people and the need to reestablish peace, democracy, the rule of law, social justice, the dignity and integrity of all Somalis". It is significant that human rights violations are mentioned in the preamble of the new charter because it acknowledges the role of human rights abuses in the state's collapse and the need to make human rights central to all endeavours to reconstruct it. This is the first charter adopted in Somalia since the collapse of the central government in 1991. The fact that armed faction leaders were not involved in the process of drafting the new document made it easier for the drafters to acknowledge the paramount importance of human rights observance. The Transitional National Charter, adopted in Arta, Djibouti in 2000, recognised regional autonomy as the new governance structure based on the 18 regions that existed before the collapse of the central government in 1991. The new charter also envisaged the separation of powers of the branches of the state such as the legislative, executive and the judiciary. 
The protection of human rights and adherence to international human rights standards gained prominence in the new charter. For instance, article 3 reaffirms that Somalia will adhere to international human rights instruments to which it is a party and provides for the supremacy of law. In the same vein, article 4 recognises the Universal Declaration of Human Rights and reaffirms the intention to implement the provisions of the two international human rights covenants both of which Somalia is a state party. Along the same line, articles 5 to 10 catalogue rights and freedoms accorded to the citizens including the right to life, freedom of movement and assembly, free speech and press freedom. The right to political participation is also enshrined in the charter. It is essential to note that, the transitional national charter also called for the establishment of an independent human rights commission.

Equally, the 2004 Transitional Federal Charter adopted during the Somali reconciliation conference in Mbagathi, Kenya, explicitly incorporates the rights enshrined in the international human rights instruments. It seems that some of the provisions even surpass the rights guaranteed by advanced democracies. The Transitional Federal Charter takes a monist approach as opposed to dualist approach to international law (Maniruzzaman, 2001). That means that it abides by the provisions of the international human rights treaties to which Somalia is a party without any need to enact any further separate domestic laws. In that regard article 14 provides that Somali Republic "shall recognize and enforce all international human rights conventions and treaties to which the Republic is a party."Article 11 paragraph 3 of the TFC stipulates that "(a) While the new Constitution is being drafted, a National Census shall be undertaken simultaneously. (b) After which an internationally supervised National Referendum shall be undertaken to approve the new Constitution". Additionally, article 4 of TFC specifies that the provisions in the charter should be interpreted in a manner that "national reconciliation, unity and democratic values". In fact, the new provisional constitution was not approved by a popular referendum, but was adopted by a selected constituent assembly in August 2012.

Likewise, numerous other citizens rights are enumerated in the charter including the equality of citizens before the law (art.16), right to life, personal liberty and security (art.16), the right to assemble and the freedom to strike (art.19). Article 24 guarantees the right of every citizen to primary and secondary education. Article 25 provides for the rights to health care stipulating: "it shall be the responsibility of the government to protect and provide public health, safe motherhood and control of communicable disease".

Nevertheless, in the absence of security and a functioning authority to willingly uphold the provisions of the constitution, the human rights violation in the country hascontinued without substantial interruptions. Experience from different parts of the world "has shown that many constitutions... have often been mere 'window dressing' rather 
than substantive protection for individual human rights" (Keith, 2002, p. 112). In that regard, the provisions in the Somali constitution, in the words of some commentators, could be characterised as purely "worthless scraps of papers" (Howard, 1991, p. 30). First, there are no meaningful courts, police forces or any other institutions to guarantee the rights enumerated in the document. Secondly, and more revealingly, most leaders of the successive transitional governments since the total collapse of the central government in 1991 have been individuals accused of masterminding the massive human rights violations of the country. Even the leaders of the current federal government who were not involved in past human rights abuses failed to establish the measures necessary to make the constitution relevant for the citizens. Lack of security is one of the reasons the rights enshrined in the constitution do not offer protection to citizens.

\section{Prioritising Security Sector Rebuilding}

There is a widespread consensus among scholars that, central to the political stability and to the reinstitution of viable, effective and legitimate public order in Somalia is the re-institution of effective internal security institutions including the police force, criminal justice and correctional systems. Experience elsewhere overwhelmingly offer evidence that, "long-term prospects for democratic governance and stability depend especially upon viable police, security forces, and justice structures to deal with the most salient internal threats..." (Wilson, 2006, p. 153). If public order is not restored immediately after the collapse of the ancient regime, it is likely that criminal forces will fill the void and use their newly acquired power for personal gain. In that regard, if peace and stability is to take hold and be sustainable, it is imperative that after silencing the guns, the first priority should be to create a credible internal security system without which any governance system cannot be established, as Puntman suggests:

Priority should be given to the demobilization of soldiers and the demilitarisation of politics; that is, the transformation of soldiers into civilians and warring armies into political parties. The achievement of important normative goals such as protection of human rights and creation of accountability and democracy depends on the implementation of these transformations" (Stedman, Rothchild, \& Cousens, 2002, p. 3).

In many conflict situations, nevertheless, reconstituting or reconstructing the police force is fraught with immense challenges. For instance, many members of the former police force may be implicated in human rights violations and corruption; and others may have actively taken part in the civil war in different capacities (Baker, 2006). In fully collapsed states where state institutions, including the police, have disintegrated and not functioned for years, it is more difficult and challenging to create a coherent and credible police force that can earn the trust of the public and thus legitimacy. The immediate challenge is to make a decision on whether to rebuild the old police 
force, albeit with some reform, or start from scratch. Recreating the old police force and returning to ante-bellum may not offer solace, and may exacerbate the situation, given the fact that more often than not "oppressive policing, nepotism and corruption" characterised the old order. Furthermore, the repressive nature of pubic policing and its concomitant human rights violations were all "contributory factors to the outbreak and continuance of conflict" (Baker, 2006, p. 28).

As Baker catalogues, experiences elsewhere in Africa show that there are three possible ways to reinstitute a legitimate and effective police force. The first option is to purge the old police force and start recruiting a complete new force as was the case in Namibia. The second possibility is to reconstitute the old police force after subjecting them to meticulous screening and selection, purging anyone implicated in human rights abuses or other criminal activity and retaining the rest. This method was employed in Angola. The third way is to keep the rank and file of the old police force and complement them with new recruits and management. This last option was used by Sierra Leone, Democratic Republic of Congo, Liberia and Rwanda (Baker, 2006, p. 29).

To be able to construct an effective and legitimate sustainable internal security, several serious conditions should be fulfilled that might contribute to the achievement of that goal. First and foremost is the existence of a functioning government which meets the requirement of the Weberian "monopoly of the legitimate use of physical forces within a given territory". In Somalia, a security sector assessment was carried out jointly by the United Nations Political Office for Somalia (UNPOS) and the United Nations with the cooperation of several countries and organisations including the Transitional Federal Government of Somalia, the African Union and the European Union. The Assessment was completed in January 2010. One of the key conclusions of the assessment was "the security sector reform may not be sustainable if a broader political foundation is not firmly established within the time frame of the transition to promote good governance, transparency and accountability" (UNSC, Report of the Secretary-General on the Situation in Somalia, 2010). Almost six years later, little seemed to change. The current police and military contingent of the government are mostly former militia members from the capital and the surrounding regions. Likewise, troops in other regions are clan militia loyal to the respective local administration. In the past, there were calls to integrate the different militias to form a credible national security force. In May 2015, the Somali government reportedly launched a new military academy designed to integrate disparate militia forces in different parts of the country.

It is not clear yet how this integration drive will work. However, the newly appointed commission for Somali national army integration stated that they intend to integrate the militias loyal to different administrations without any vetting process. To make matters worse, in the last ten years countless ex-militiamen and civilians without any prior military or police experience have been promoted to the rank of general. 
In consequence, attempts to reconstruct the collapsed state of Somalia and its institutions have failed, because human rights were not made central in all efforts. A competent national police force is a prerequisite "for the restoration of the rule of law and of public security, but also crucial to the broader process of restoring state legitimacy and a state-held monopoly on the legitimate use of force" (Donais, 2005, p. 271). For Somalia to have any chance of arresting the downward spiral of statelessness, violence and human rights violations, an effective security system should be established. In turn, for security forces to be effective a legitimate authority must be in place to gain the trust of the population in the new security force.

\section{Rebuilding the Justice Sector}

In societies emerging from prolonged civil wars, it is argued "the justice system can play an important role both in successful investigation of past abuses of human rights and in effective prevention of future violations" (Wardak, 2004, p. 331). However, if individuals accused of perpetrating heinous atrocities are given influential positions of power, it is unlikely that any meaningful investigation can take place. As Wilets notes, "human rights cannot be respected in a vacuum. Acceptance of human rights treaties and formal acceptance of human rights norms is meaningless without the rule of law" (Wilets, 2001, p. 597).

Wilets continued, "the rule of law cannot exist unless society itself creates independent civic institutions to monitor observance of human rights and encourage compliance with human rights norms" (Wilets, 2001, p. 599). In Somalia, after decades of violent civil war between various warring parties and a total collapse of all central government institutions, reinstituting a sustainable justice system is a tremendously daunting task. All the justice infrastructure including police stations and headquarters, prison facilities and courthouses have been destroyed. Equally, all government personnel including police officers, judges and prison officers have either left the country, are living in exile, or are accused of taking part in past human rights violations. Against this rather bleak backdrop, new government institutions have to be re-established from scratch for there are no institutions to be reformed.

In May 2012, the independent expert on human rights urged the leaders of the transitional government to restore the justice system. The UN expert, Shamsul Bari stated: 'Strengthening access to justice and rule of law in the country is crucial to protect and promote the fundamental rights of the Somali people'. Furthermore, the independent expert recognised, "[r]e-establishing a legitimate justice system in Mogadishu and South-Central Somalia presents a major challenge, but also an opportunity for the international community". He was alarmed by the "total collapse of the institutions for law enforcement and the administration of justice". ${ }^{2}$ It is clear from this statement

2 UN News Centre, UN expert on Human Rights in Somalia Urges Restoration of Justice System, 02 May 2012 
that the efforts of the last two decades to re-establish a functioning justice system on a national level have been unsuccessful. Second,without a working justice system, other efforts to consolidate state institutions will have little impact on the conflict situation.

To create a legitimate justice system, it is imperative to identify individuals who were tainted by human rights abuses and corruption. If these individuals are allowed to get involved again the credibility of the whole system would be in jeopardy. In post Saddam Hussein Iraq, a Judicial Review System was put in place to screen all former employees and purge anyone involved with previous offenses. In consequence, "over 800 judges and prosecutors had been investigated and approximately 170 were removed" (Williamson, 2004 , p. 238). However, several factors influence or determine the options available to the new authority. To be sure, the duration of the conflict and the effectiveness of its institutions play a pivotal role. For instance, totally collapsed states like Somalia embroiled in ongoing conflict may have more limited options than in a situation where one group won the civil war, like Rwanda or where the conflict ended due to a negotiated settlement like Mozambique and Democratic Republic of Congo.

State reform covers more than the mere rebuilding of institutions and a change of individuals. In addition to "forging democratic development, the participation of the population and the rule of law, it will also develop structures that can offer an effective means for the peaceful management of deep rooted conflict". Additionally, "poorly designed state reform can even lead to the deterioration of a conflict" (Baechler, 2004, p. 2). As Baechler rightly observes: "If a transition process to peace and development is to be sustainable, it must enjoy the support of the entire population and not only the political elite" (Baechler, 2004, p. 4). It seems that the manner in which leaders come to power has a profound bearing on the way the country is subsequently governed. For example, Baechler argues that "[b]ad governance and poor state performance quite often coincide with leadership that has reached power through a coup d'état, secession or civil war" (Baechler, 2004, p. 6). It is also recognised that maintenance of law and order "is a multi-dimensional effort that not only comprises the police but also the prosecution service, judiciary and correctional systems" (Strohmeyer, 2001, p. 171). The next sections will separately analyse the different components, like the necessity to reform police and judicial systems, as an overall project.

\subsection{Building a Credible Police Force}

The reconstruction of national institutions is challenging, and as the Secretary-General of the United Nations acknowledged: "Restoring the capacity and legitimacy of national institutions is a long-term undertaking. However, urgent action to restore human security, human rights and the rule of law cannot be deferred" (UN, Report of the Secretary-General on the Rule of Lawand Transitional Justice in Conflict and Post Conflict Societies, 2004). Charles Call (2008) articulately argues that police reform is informed by five different perspectives. He further asserts that these perspectives 
overlap and are not necessarily mutually exclusive. The first one is the human rights perspective which entails the necessity to embed international human rights standards in all facets of police work. In this perspective, all human rights violators are removed from the forces and new recruits need to undergo rigorous vetting so as not to admit any human rights abuser into the police force. The second one is the peacekeeping perspective which is concerned with maintaining peace and stability by integrating all the different combatants into one coherent force. In this perspective, all the actions of the police and its reconstitution are geared towards preventing a recurrence of the violent conflict. Unlike the human rights perspective, the human rights record of the members of the police force is not a serious concern.

The third is a law-enforcement perspective, which focuses on creating an effective police force capable of combating crime. Consistent in some respects with the peace-keeping perspective, this approach is not necessarily concerned with the past activities of the recruits or old officers. Rather, the emphasis is on retaining more experienced police officers who are able to pass their invaluable knowledge and experience to the new recruits. Obviously, this perspective ignores other possible methods to gain experience without legitimizing the past criminal activities of the police officers. The fourth perspective is the economic development perspective which is somewhat related to the law-enforcement perspective, both of which emphasize control of crime so that a safe environment conducive to investment can be created. Finally, there is the democratization perspective which focuses on not only human rights but is also concerned with the broader rule of law and criminal justice issues (Call, 2002, pp. 100-110).

It seems that almost all attempts to rebuild the Somali police and justice system have been along the lines of the peacekeeping perspective detailed above and to a lesser extent the law-enforcement perspective. After the collapse of the central government in 1991, the central police authority disintegrated, and police officers fled to their respective hometowns and villages. Some directly participated in the civil war while others were recruited by local administrations to be part of the local police force. The UN intervention force attempted to train and reinstate police forces in their respective locality (Halim, 1996). However, as soon as the UN troops withdrew from Somalia in 1995, members of the police forces trained to fill the security void dispersed. From then on, despite attempts from the transitional leaders and the international community, no national police force became operational until 2001.

In 2000, after a decade without a central government, a transitional national government was established as a result of a reconciliation conference held in Arta, Djibouti. The transitional national government tried to reconstitute the national police force. The members of the police force consisted of some old police officers who were trained before the outbreak of the state collapse and others recruited from the faction leaders. These former militia members lacked discipline, equipment, and the wider public 
had no trust in them. Furthermore, and more worryingly, a known warlord who had been accused of massive human rights violations was named as the commander of the national police force. He recruited his militia members from local warlords who owed allegiances to their clan or faction leader. When the term of the transitional government was about to end, he defected from the government taking most of the police force with their equipment and subsequently used them as his militia, manning illegal roadblocks and running extortion activities. In 2002, an Amnesty International report documented the human rights abuses perpetrated by the police force and other militia groups. ${ }^{3}$

After almost fifteen years of attempts to reconstruct the Somali police force, it is commonly acknowledged that no meaningful headway has been made in establishing a sustainable local police force capable of maintaining law and order and ensuring the security of the citizens. The pertinent question that might be asked is: why have different efforts failed so far?. In conflict shattered countries like Somalia, security generally entails arresting ongoing hostilities, demobilising and rehabilitating the former combatants, the reinstitution of effective and legitimate central government and securing the country's borders from external threats. It is essential to understand the nexus between civil security and state security which are often complementary.

In that respect, "state security concerns rise and fall with the level of threat against a nation, while civil security must always be present to ensure the rule of law and "to keep the peace" (Murry, 2011). As often is the case, by and large state security is usually protected by national military forces and intelligence services in collaboration. On the other hand, "civil security is the preserve of civilian police. While there is some blurring at the line of demarcation, as a general principle, police do not fight wars, and national armies are not used against civilian populations" (Murry, 2011).

In November 2011, according to the United Nations, the Transitional Federal Government had approximately 10,300 security forces in the capital city alone, including troops trained by the European Union in Uganda (UNSC, Report of the Secretary-General on the Situation in Somalia, 2011, p. para.36). However, attempts to reconstruct state institutions, which are prerequisite for building effective governance, neglected the root causes of the conflict including human rights violations, and concentrated on tackling the symptoms of the conflict. Warring militias beholden to the warlords or faction leaders formed the backbone of all the police and military force. As a result, infighting, widespread mistrust of the people and defecting to his old militia when his warlord patron is dissatisfied with the political dealing of the day characterised the police recruitment exercises. For instance, after spending millions of dollars on recruitment and training in the capital city Mogadishu, according to the United Nations, "there are numerous reports of looting, murder and sexual violence carried out by armed men in military uniforms

3 Amnesty International Report 2002, AL index: POL 10/001/2002 
against internationally displaced people" (UNSC, Report of the Secretary-General on the Situation in Somalia, 2011, p. para.68). The alleged corruption of the government institutions including the police force is also widespread.

Police reform is challenging particularly in situations where the police force has been accused of committing heinous crimes under the previous government. It is much more daunting and difficult in circumstances where the police force has disintegrated and has been out of action for more than a decade. As O'Neill agues: "police reform takes a long time, involves transforming power relations in a society and requires more than technical tinkering with police doctrine and practice" (O'Neill, 2005, p. 2). Furthermore, "police reform must be carried out in tandem with judicial reform. Modernizing laws, training judges, making courts more efficient and humanising prisons are all part of 'rule of law'" (O'Neill, 2005, p. 3). As O'Neil further argues that, "training and increased knowledge of rights will not single-handedly change behaviour or prevent human rights violations by police" (O'Neill, 2005, p. 4).

However, any amount of training could not transform the corrupt police force if there is no possibility of an independent complaint mechanism and enforcement. The current Federal Government troops are mostly comprised from militia of the warlords and faction leaders who have been involved in the civil war and human rights violations in the past decades. Furthermore, most of the military and police commanders are former officers who served under the repressive military government. No attempt has been made to vet and screen them. In that respect, it is unreasonable to expect them to safeguard the human rights of the citizens. The Secretary-General of the United Nations reported, "[p]oor command and control over TFG forces and the loose integration of militia and clan-based divisions led to a serious of incidents resulting in civilian casualties" (UNSC, Report of the Secretary General on the Situation in Somalia, 2011, p. para.28).

During the United Nations intervention in Somalia in the early 1990s, the United Nations mission allocated a lot of financial resources and manpower to training the police force and refurbishing courts and police stations. The Security Council recognised that reconstituting an effective police force, judicial and penal system is a prerequisite for the creation of a peaceful and stable environment in Somalia. ${ }^{4}$ In that respect, the United Nations and donor countries spent a considerable amount of money and resources to train Somali police force. In May 1994, the total number of police officers recruited and trained was 7,799. The initial UNOSOM policy regarding re-establishment of the Somali police was that only individuals who served a minimum of two years as a police officer in the previous military government was eligible for the new recruitment.

However, it seems that the United Nations overlooked the fact that, without a legitimate domestic political authority or other governance structure in place, all these efforts were

4 SC Res 865 (1993) 
in vain. That is exactly what happened when the UNOSOM II troops were withdrawn; the trained police dispersed and court and police buildings were taken over by local militias loyal to different faction leaders. In that respect, the United Nations later admitted, " $[\mathrm{t}]$ he protracted political impasse has created a vacuum of civil authority and of governmental structure, leaving the United Nations with no function to build on its efforts to help Somalia emerge from its present chaotic condition". As a consequence, "the presence of UNOSOM II troops has had limited impact on the peace process... and security". Sometimes it is easier and much more efficient to recruit and train new police force who are not tainted by corruption or any other ill practice.

If we sufficiently analyse the successive Somali governments established in the last decade and half, and their attempts to reconstitute the police and military force, a clear pattern emerges. First, a transitional government is formed mostly comprising warlords. Former government officials without any vetting or clear strategy are trusted to reconstruct a legitimate authority in the country. Subsequently, the United Nations, donor countries and human rights organisations enthusiastically welcome the new government and urge them to respect human rights. After that, the government brings the militia of the warlords without any vetting or proper training and lets them police the areas under the control of the government. Given their past activities and the lack of any future safeguards to protect the abuses of the police and military personnel, the population continues with their distrust of the police and the military. The UN provides training and human rights protection lessons, but to no avail. When a new government is created the cycle starts all over again.

For example, in 2009, immediately after the creation of the transitional government after the Djibouti agreement, the United Nations suggested that:"[i]n the short-term, the Somali police force needs advice, ongoing training and logistical support through a trust fund". The report went on to state: "In the medium term, infrastructure and specialised police training will be essential". Surprisingly, the UN notes, "in the long term police reform and a restructuring programme should be implemented in line with the national security sector strategy for Somalia" ${ }^{\prime}$. It appears a confused prioritisation. Training and equipping first, and thinking about reform and restructuring later. There are several problems with this proposal. First, it seems that the UN and other organisations conveniently overlook the fact that a known warlord was named as police chief and "re-hatted" his militia to become the police force. Second, and more worryingly, this statement suggests that money and resources should be invested in training and strengthening warlords, before making another effort to "reform". It is likely that the new police will be resistant to the proposed reform as it collides with their warlord's vision of maintaining the status quo.

5 UN Security Council, Report of the Secretary-General on the Situation in Somalia, S/2009/132, 9 March 2009, para.42 
Since its inception, tens of thousands of both military and police personnel have been trained for the Transitional Government of Somalia. These troops have not only failed to protect the civilians but they actively participated in violating their basic rights. More strikingly still, there is constant infighting between different groups within the troops themselves. For example, recently when the European Union announced that it would train military forces for the Somali government, warlord militia or clan militia had been sent to be trained as the new security force without any vetting. In consequence, the wider public had no faith in the forces trained to restore order, thus lack any legitimacy in the eyes of the populace. Such situations inevitably create circumstances where victims of warlord militia are confronted with their erstwhile oppressors who are now supposed to be the ones responsible for their safety. This puts the pubic in an uneasy situation. Even though they are willing to support the new authority, they cannot trust the enforcement arms of that authority. The fact that no one is held to account for the previous atrocities makes the situation more complicated. If the perpetrators of past human rights abuses confess and seek forgiveness, this might give the public a reason to give the new recruits the benefit of the doubt. However, known criminals and their leaders have been selected to maintain public order without any safeguards or means to seek remedy for any future transgressions on the part of the security forces. In that light, there is constant deadly infighting between government forces loyal to different former warlords or other individuals. If for whatever political reason it is decided to retain the old police force without any vetting, it is essential to create a complaints procedure and an internal organ within the police force where the public can report police abuses, corruption or any other dissatisfaction. Experience elsewhere in Africa shows that such measures givethe public confidence that their complaint will be heard. For instance, In Sierra Leone a "Complaints Discipline and Internal Investigation Department" was instituted to give the wider public an opportunity to report any police malpractice such as human rights violation and bribery. Following complaints from the public and subsequent investigations, roughly 100 police officers accused of various malpractices were dismissed between 2001 and 2006 (Baker, 2006, pp. 33,35).

To have any chance of success, police reform and other efforts to rebuild effective police forces must be part of a broader institutional building exercise. In Somalia, there have been at least three instances where the international community attempted to support the reinstitution of Somali national police force. First, during the UN intervention in the early 1990s, an attempt was made to rebuild a police force at the local level. There were also separate developments at regional level. The United Nations and other donor countries are also involved in helping some parts of Somalia, particularly Somaliland and Puntland, to create a functioning justice system including police, judiciary and penal facilities.

Interestingly, in all attempts to reconstruct the Somali national police or military force, scant attention has been given to the past activities of the police force or the current 
political organisations of the present leaders. During the military government and subsequent transitional governments, both the police and military have been implicated in massive human rights abuses. As experiences elsewhere amply reveal, effective policing does not only require recruiting individuals for the force, but also requires:

the establishment of political architecture of public safety, a complex of justice-oriented governance mechanisms that link policing agencies not just to prosecutors, courts and corrections, but also to the exercise of ministerial power and planning and control of resources by bureaucrats (Goldsmith \& Dinne, 2007).

For any police force to win the trust of the people, the support and acceptance of the population is essential. Different approaches are chosen to achieve that goal. For instance, in Haiti and El Salvador, the preference was not to rely on the old tainted police force but to start from scratch with the new security force. However, it is necessary to realise that, police reform without broader political reform is not going to work (Donais, 2005, p. 4). In Somalia where the police force and other state institutions have not been functioning for the last two decades, it is less attractive to recall the old police force for several reasons. First, most members of the police force are known for their corruption and oppression. They were used by the previous military government to repress dissent. Second, and perhaps more pertinent, the majority of the old police force have passed retirement age. For any reform to work, the whole justice sector should be reformed including the police, judiciary and penitentiary system. After more than twenty years without functioning institutions on a national level, the facilities are either entirely destroyed or are crumbling. The lack of security forces has given rise to private armies and local militia which in turn has created insecurity and led to widespread human rights abuses. The police force of the federal government is faction-ridden and is incapable of fulfilling policing duties even within only the capital city, let alone the whole country. It is not only necessary to reform the police force, but this has to occur in tandem with judicial reform.

\section{Concluding Remarks}

In a report to the Security Council in May 2010, the UN Secretary-General pertinently described the dire human rights situation in Somalia: "[t]he overall security situation in Somalia remains highly volatile and unpredictable"6. Equally, the Secretary-General noted that the "human rights situation in Somalia has been among the most neglected in the world..."7. This indubitably demonstrates that all the efforts in the last two and

6 UN SC, Report of the Secretary-General on the Situation in Somalia, S/2010/234, 11 May 2010, para. 8

7 UN Security Council, Report of the Secretary-General on the Situation in Somalia, S/2009/132, 9 March 2009, para. 44 
half decades failed to ameliorate the suffering of the population satisfactorily. In consequence, massive human rights violations continue insubstantial parts of the country unabated.

Usually human rights abuses occur both horizontally and vertically. The vertical human rights violations entail state agents abusing the rights of the citizens, being unable to protect them, or by creating an environment where human rights violations are tolerated. With respect to horizontal human rights, abuses occur between citizens without the involvement of state agents. Usually, a state without proper checks and balances violates the human rights of the people under its jurisdiction. Initially it was though that states with too much power were prime enemies of human rights. However, there is a belated realisation that a complete lack of state institutions is more a threat to the human rights than too much of it. In situations where state institutions are ruined the twin functions of the state are unfulfilled. For a start, the state does not hold the monopoly on the legitimate use of violence. As a result, the state is unable to provide any political goods like health, education, security and economic development. The two functions are intertwined and interdependent.

In Somalia's case, the prolonged conflict has made the majority of citizens passive spectators because "many citizens are hesitant to become overly involved in the political rebuilding process, having been conditioned by wartime realities to defer to individuals who exercised authority through the barrel of the gun" (Orr, 202, p. 139). Evidently, "the single most important factor that determines the success or failure of a post-conflict reconstruction effort is the extent to which a coherent, legitimate government exists- or can be created" (Orr, 202). In that connection, it is crucial that the international effort to help the collapsed states to create legitimate governance should revolve around two specific activities.

First, all the efforts must be directed at creating a legitimate governance structure. The best way to create such a legitimate government is to make certain that, in accordance with international human rights standards, the population have unhindered access to the political process and can extend this participation. To that end, creating a government with no support from the population is not enough and might exacerbate the already calamitous situation. Second, once a legitimate entity is constituted, its capacity should be strengthened so as to enable it to provide essential public goods which in turn would further augment the legitimacy of the new government (Orr, 202, p. 140). Unless that happens all the efforts towards human rights protection in Somalia will likely remain ineffective. 


\section{References}

1. Ahmed, S. (2005). No Size Fits All: Lessons in Making Peace and Rebuilding States. Foreign Affairs, 84(1), 162-169.

2. Amnesty International (1995). Somalia: Building Human Rights in the Desintegrated State. London: AI Index: AFR 52/03/95.

3. Annan, K. (1998). The Causes of Conflict and the Promotion of Durable Peace and Sustainable Development in Africa. Report of the Secretary-General to the Security Council.

4. Baechler, G. (2004). Conflict Transformation Through State Reform. VS Verlag Fur Sozialwissenschaften.

5. Baker, B. (2006). The African Post-conflict Policing Agenda in Sierra Leone. Conflict, Security and Development, 6(1), 25-49.

6. Benomar, J. (2004). Constitution-Making After Conflict: Lessons for Iraq. Journal of Democracy, 15(2), 81-95.

7. Brahimi, L. (2007, June 26-29). State-building in Crisis and Post-conflict Countries. 7th Global Forum on Reinventing Building Trust.

8. Brinkerhoff, D. (2005). Rebuilding Governance in Failed States and Post-conflict Societies: Core Concepts and Cross-Cutting Themes. Public Administration and Development, 25(1), 3-14.

9. Bush, K. (1997). When Two Anarchies Meet: International Intervention in Somalia. Journal of Conflict Studies, 17(1), 55-78.

10. Call, C. (2002). Competing Donor Approaches to Post- Conflict Police Reform. Conflict, Security \& Development, 2(1), 99-120.

11. Call, C. (2008). The Fallacy of the 'Failed States'. Third World Quarterly, 29(8), 1491-1507.

12. Caplan, R. (2004). International Authority and the State Building : The Case of Bosnia Herzegovina. Global Governance, 10(1), 53-65.

13. Dodge, T. (2005). Iraqi Transitions: From Regime Change to State Collapse. Third World Quarterly, 26(4/5), 705-721.

14. Donais, I. (2005). Back to Square One: The Politics of Police Reform in Haiti. Civil Wars, $7(3), 270-287$.

15. Elmi, A. A. (2012). REvisiting the UN-Controlled Constitution-Making Process for Somalia. E-International Relations. Retrieved from www.e-ir.info/2012/09/02/revisit ing-the-un-controlled-constitution-making-process-for-somalia/.

16. Goldsmith, A., \& Dinne, S. (2007). Transnational Police Building: Critical Lessons from Timor-Leste and Solomon Islands. Third World Quarterly, 28(6), 1091-1109.

17. Halim, 0. (1996). A peacekeeper's Perspective of Peacebuilding in Somalia. International Peacekeeping, 3(2), 70-86.

18. Hannum, H. (2006). Human Rights in Conflict Resolution: The Role of the High Commissioner for Human Rights in UN Peacekeeping and Peace-building. Human Rights Quarterly, 1-85.

19. Hart, V. (2003). Democratic Constitution Making. United States Institute of Peace, Washington, D.C. 
20. Howard, A. (1991). The Essence of Constitutionalism. In W. T. Ludwikowski, Constitutionalism and Human Rights: America, Poland, and France (pp. 18-30). Yew York: Lanham.

21. ICG. (2011). Somalia: The Transitional Governement on Life Support. ICG.

22. Ignatieff, M. (2005). 'Human Rights, Power and the State. In S. Chesterman, M. Ignatieff and R. Thakur (Eds.), Making States Work: State Failure and the Crisis of Governance (pp. 35-59). Tokyo: UNited Nations University Press.

23. Katoboro, J. (2003). Democratic Institution Building In Post-Conflict Societies. UNDESA Commissioned Paper for Fifth International Conference on New and Restored Democracies, (pp. 1-28). Ulaanbaatar.

24. Keith, L. C. (2002). Constitutional Provisions for Individual Human Rights (1977-1996): Are They More than Mere "Window Dressing"? Political Research Quarterly, 55(1), 111143.

25. Khayre, A. (2014). Self-Defence, Intervention by Invitation, or Proxy War? The Legality of the 2006 Ethiopian Invasion of Somalia. African Journal of International adn Comparative Law, 22(2), 208-233.

26. Khayre, A. A. (2016). Politics of Justice, Human Rights and Reconciliation in the Collapsed State of Somalia. Amsterdam law Forum, 8, 3-27.

27. Kumar, K. (1997). Rebuilding States after CivilmWar: Critical Roles for International Assistance. Boulder, Co.: Lynne Rienner.

28. Lederacht, P. (1997). Building Peace. Washington, D.C: United States Institute of Peace.

29. Maniruzzaman, A. (2001). State Contracts in Contemporary International Law: Monist versus Dualist Controversies. European Journal of International Law, 12(3), 309-328.

30. Murry, T. (2011). Police-building in Afghanistan: A Case Study of Civil Security Reform. International Peacekeeping, 14(1), 108-126.

31. Nash, K. (2009). The Cultural Politics of Human Rights. Cambridge: Cambridge University Press.

32. Nationality Decrees Issued in Tunis and Maroco, Advisory Opinion, 4 (P.C.I.J February 7, 1923).

33. O'Neill, W. (2005). Police Reform in Post-Conflict Societies: What We Know and What We Still Need to Know. New York: International Peace Academy.

34. Orr, R. (202). Governing When Chaos Rules: Enhansing Governance and Participation. Washington Quarterly, 25(4), 139-152.

35. Putnam, T. (2002). Human Rights and Sustainable Peace. In D. R. Stephen Stedman, Endign Civil Wars : The Implementation of Peace Agreements (pp. 237-271). Boulder, Co.: Lynne Rienner.

36. Reisman, W. M. (1990). Soverignty and Human Rights in Contemporary International Law. American Journal of International law, 84, 866-876.

37. Rothschild, a. D. (Ed.). (1998). 'Ethnic Fears and Global Engagement', the International Spread of Ethnic Conflict. Princeton: Princeton University Press.

38. Rothstein, R. (1999). Fragile Peace and Its Aftermath. After the Peace: Resistence and Reconciliation. Boulder, C.: Lynne Rienner. 
39. Sahnoun, M. (1997). Prevention in Conflict Resolution. In H. A. Ford, Mending the Rips in the Sky: Options for Somali Communitiesin the 21st Century. Lawrenceville,NJ: Red Sea Press.

40. Sahnoun, M. (1994). Prevention in Conflict Resolution: The Case of Somalia. International Affairs, 5-13.

41. Samuels, K. (2006). Post-conflict Peace-building and Constitution-Making. Chicago Journal of International Law, 6, 1-20.

42. Shabas, W. a. (2007). Respect, Protect and Fulfil: a Human Rights-based Approach to Peacebuilding and Reconciliation. Monaghan, Co.: Border Action.

43. Spence, R. (2001). Post-Conflict Peacebuilding: Who Determines the Peace. In B. \&. EvensKent (Ed.), Rethinking Humanitarian (pp. 137-8). St. Lucia: University of Queenland.

44. Stedman S. J., Rothchild, D., \& Cousens, E. (2002). Ending Civil Wars: The Implementation of Peace Agreements. Boulder, Co.: Lynne Rienner

45. Strohmeyer, H. (2001). Policing the Peace: Post-Conflict Judicial System Reconstruction in East Timor. University of South Wales Law Journal, 24(1), 171-187.

46. UN Commission on Human Rights. (1994). Report by the Independent Expert, Fanuel Jariretundu Kozonquizi, on the Condistion in Somalia.

47. UN Commission on Human Rights. (2004). Situation of Human Rights in Somalia: report of the Independent Expert, Ghanim Alnajjar. Human Rights Commission.

48. UN Commission on Human Rights. (2005). Situation of Human Rights in Somalia: Report of the Independent Expert, Ghanim Alnajjar.

49. UN. (2004). Report of the Secratary-General's High-Level Panel on Threats, Challenges and Change- A More Secure World: Our Shared Responsibility.

50. UN. (2004). Report of the Secretary-General on the Rule of Lawand Transitional Justice in Conflict and Post Conflict Societies. Yew York: United Nations.

51. UNGA-UNSC. (1998). The Causes of Conflict and Promotion of Durable Peace and Sustainable Development in Africa. United Nations.

52. UNSC. (1994). Further Report of the Secretary-General on the United Nations Operations in Somalia. New York: United Nations.

53. UNSC. (2001). Report of the Secretary-General on the Situation in Somalia. New York: United Nations.

54. UNSC. (2010). Report of the Secretary-General on the Situation in Somalia. New York: United Nations.

55. UNSC. (2011). Report of the Secretary-General on the Situation in Somalia. New York: United Nations.

56. UNSC-UNGA. (2003). Interim Report of the Secretary-General on the Prevention of Armed Conflict. New York: United Nations.

57. Wardak, A. (2004). Building a Post-War Justice System in Afghanistan. Crime, Law \& Social Change, 41, 319-341.

58. Wilets, J. (2001). The Building Blocks to Recognition of Human Rights and Democracy: Reconciliation, Rule of Law, and Domestic and International Peace. ILSA Journal of International and Comparative Law, 7, 597-603. 
59. Williamson, J. (2004). Establishing Rule of Law in Post-War Iraq: Rebuilding the Justice System. Georgia Journal of International and Comparative Law, 33, 229-244.

60. Wilson, J. (2006). Law and Order in an Emerging Democracy: Lessons form the Reconstruction of Kosovo's Police and Justice Systems. Annals of the American Academy of Political and Social Science, 605, 152-177. 